\title{
ŚMIERĆ-PIASTUNKA DAJE UKOJENIE. O MŁODOPOLSKIM WYOBRAŻENIU ŚMIERCI W WYBranYCh WIERSZaCh BronišaWy OstrowsKIEj I MaryLi WolsKiej
}

Śmierć (w różnych wariantach i zestawieniach) stanowi jeden z ważniejszych tematów literatury okresu Młodej Polski. Wiadomo, że mówienie lub pisanie o niej z reguły wydaje się kłopotliwe, gdyż przeżycie to jest nieprzekazywalne obserwatorom, a doświadczenie śmierci samo w sobie należy chyba do najbardziej traumatycznych dla człowieka. Śmierć stanowi wielką zagadkę, na której temat trudno się wypowiadać, gdyż nie można dotrzeć do jej istoty i następnie poddać analizie. Na poziomie ontologicznym możliwe jest poruszanie się jedynie wśród opisów, które są wynikiem domysłów na temat samego zjawiska śmierci.

Śmierć ponadto posiada rzeczywisty wpływ na pozostające pod jej władzą środowisko społeczne. Umieranie kogoś skutkuje przenikaniem śmierci do wielu sfer ludzkiego życia. Pewność tego doświadczenia jest wpisana w ciągłość egzystencji człowieka. Jednak szczególnie wyraźne przekonanie mówiące o wyczerpalności życia pojawia się w momentach dla człowieka kryzysowych — na przykład w czasie ciężkiej choroby i w kontekście jej skutków. Towarzyszy też świadomości upływającego czasu, który objawia się u ludzi (i pozostałych istot żyjących) postępującym procesem starzenia. $\mathrm{Z}$ biologicznego punktu widzenia stanowi nieodwracalne zatrzymanie wszystkich czynności życiowych, a tym samym kres ziemskiego żywota². Śmierć posiada więc wymiar psychologiczny, społeczny, medyczny, kulturowy ${ }^{3}$. Istnieje również w sferze języka.

W literackich przekazach zjawisko to funkcjonuje jako nieodłączny element ludzkiej egzystencji, powodujący lęk, czasem ulgę, a przede wszystkim wzbudzający ogromne zaciekawienie.

Celem obecnych rozważań jest ukazanie na przykładach kilku wybranych wierszy młodopolskich poetek — Bronisławy Ostrowskiej i Maryli Wolskiej popularnej w literaturze drugiej połowy XIX wieku młodopolskiego wcielenia makabry w postaci

\footnotetext{
${ }^{1}$ Aldona Jankowska - ukończyła filologię polską na Wydziale Filologicznym Uniwersytetu Łódzkiego. Słuchaczka Studium Doktoranckiego Języka, Literatury i Kultury UŁ, doktorantka w Katedrze Literatury i Tradycji Romantyzmu. Jej zainteresowania badawcze oscylują wokół problematyki literackiej XIX wieku (szczególnie okresu romantyzmu i Młodej Polski), zagadnień dotyczących „kwestii kobiecej”, sposobów realizacji toposów miłości i erotyzmu w literaturze modernistycznej oraz malarstwie secesyjnym.

${ }^{2}$ Encyklopedia zdrowia, red. W. S. Gumułka, W. Rewerski, Warszawa 1994, s. 280.

${ }^{3}$ M. Żelichowska, Śmierć z perspektywy psychospołecznej, [w:] Śmierć jako norma. Śmierć jako skandal, red. W. Kuligowski i P. Zwierzchowski, Bydgoszcz 2004, s. 77. W strukturze przestrzennej obecność śmierci dokumentują cmentarze.
} 
śmierci-piastunki ${ }^{4}$, która wyzwalała od cierpień natury egzystencjalnej i wprowadzała w stan wyciszenia i uspokojenia. Prezentowana wybrana odsłona śmierci wiązała się z funkcją oswajania człowieka z tym, co nieuniknione.

Teresa Walas słusznie wskazuje na odmienność młodopolskiego budowania poetyckich wyobrażeń śmierci i na ich ważną rolę w tamtym czasie:

W modernizmie śmierć staje się nagle czymś dobrze widocznym i czymś niewątpliwym, dostarcza jakiejś absolutnej miary rzeczy [...], jest także aktem posłuszeństwa bytowemu prawu i przystaje do kategorii ostatecznych, jakimi chętnie posługuje się tekst dekadencki. Śmierć wyzwalała wreszcie jednostkę od istnienia, które jest istnieniem tragicznym, bolesnym i absurdalnym ${ }^{5}$.

Młoda Polska była epoką, w której doszło do przeobrażenia się wizerunku śmierci (znanego chociażby ze średniowiecznej ikonografii) i zarazem samego sposobu mówienia o niej.

W literaturze przełomu XIX i XX wieku śmierć stanowiła wręcz monotemat, obok miłości, „stały i obowiązujący”, który zgodnie z „tradycją modernistyczną” poddawano zabiegowi estetyzacji. Jak stwierdziła Antonina Lubaszewska:

Figuracją śmierci w XV i XVI wieku był szkielet, natomiast w młodopolskim ujęciu — pozbawiona cech budzących grozę — Madame Mors, która stanowiła odwrócenie średniowiecznej wersji Danse macabre? .

Śmierć upersonifikowana ujawniała gorycz życia doczesnego, które naznaczone było, zgodnie z filozofią Schopenhauera, nieustannym cierpieniem. Dlatego też młodopolskie dialogi o śmierci ukazywały przede wszystkim pozytywną stronę ,innego bytu”. Śmierć stanowiła w nich swego rodzaju wyzwolenie, a poprzez podkreślanie atrakcyjności zaświatowych krain — lepszą formę życia. Zarówno pisarze, jak i artyści, przedstawiając jej upersonifikowane oblicza, często stosowali symbolikę pór roku (jesieni i wczesnej wiosny) ${ }^{8}$, najczęściej jednak wykorzystywali motyw kościotrupa z kosą, który, zgodnie z tradycją młodopolską, zastąpiono wizerunkiem pięknej kobiety.

${ }^{4}$ Śmierć-piastunka to jedno z młodopolskich wyobrażeń śmierci. Miało ono służyć oswojeniu człowieka z doświadczeniem umierania. Do innych, upersonifikowanych obrazów śmierci w drugiej połowie XIX wieku należały matka i dziewczyna. Przykład łagodnego, konwencjonalnego opisu kresu żywota w tonacji „oswojenia” nakreślił Antoni Lange:

Bo wiem, że śmierć jest słodka, matczyne ma dłonie,

Pieszcząc kołysze do snu na białym swym łonie.

Zob. A. Lubaszewska, Życie - Śmierci doskonatość. Mtodopolska antropologia śmierci i literacki świat wartości, Kraków 1995, s. 54 i 55.

${ }^{5}$ T. Walas, Ku otchtani (dekadentyzm w literaturze polskiej 1890-1900), Kraków 1986, s. 189.

${ }^{6}$ Tamże, s. 190.

${ }^{7}$ A. Lubaszewska, $d z$. cyt., s. 54 i nast. W Młodej Polsce panowało przejęte z romantyzmu przekonanie, iż tylko w pogardzie dla śmierci jest nadzieja wyzwolenia oraz przekonanie wywodzące się od Schopenhauera mówiące o nicości bytu i ludzkiej egzystencji. Podobne wyobrażenie śmierci znajduje swoją realizację na obrazach prerafaelitów: Sen Dantego Rossettiego, Śmierć Ofelii Millaisa, Śmierć Ellenai oraz Thanatos II Malczewskiego.

${ }^{8}$ Jesień dla modernistów stanowiła alegorię wyciszającego piękna eutanazji, była również środkiem znieczulającym ból wynikający z nieuchronności przemijania. Zob. W. Gutowski, Nagie dusze i maski. O mtodopolskich mitach mitości, Kraków 1997, s. 57. 
Dzięki tej transformacji nieuniknione i trudne doświadczenie śmierci mogło stać się łatwiejsze do zrozumienia i następnie do spokojniejszego przeżycia żałoby. Człowiek, opierając się na nowym, bardziej korzystnym wizualnie wyobrażeniu zjawiska, szybciej mógł przepracować wewnętrznie zaistniałą sytuację graniczną. Wyobrażenie śmierci w łagodniejszej wersji działało w pewien sposób jak mechanizm obronny przeciw naturalistycznemu widokowi rozkładającego się ciała, a tym samym fizycznemu procesowi umierania.

Zmniejszenie lęku przed śmiercią następowało również za sprawą uświadomienia sobie, iż doświadczenie to nie ma jedynie indywidualnego charakteru, dotyczy bowiem każdego człowieka i dlatego powinno być rozpatrywane z perspektywy zbiorowości. Śmierć jest przecież zjawiskiem powszechnym, dotykającym ostatecznie każdego żyjącego. Skoro więc człowiek jest częścią większej całości, nie musi samotnie zmagać się z ciężarem śmierci. Świadomość, iż śmierć stanowi „wspólny mianownik” wszystkiego, co żyje, daje podstawę do rozumienia tego zjawiska w kategoriach „oswojenia”.

Philippe Ariès - jeden z ważniejszych przedstawicieli francuskiej tanatologii, mając na uwadze funkcję zespalającą wszystkich ludzi w obliczu śmierci, nakreślił zmieniające się na przestrzeni czasu różne jej obrazy uszeregowane w zależności od pewnych czynników?.

Co więcej, nową wizję śmierci można zestawić z zasadami obowiązującymi w myśleniu mitycznym. Mity początkowo, ze względu na niemożność naukowego wytłumaczenia prawd rządzących światem, w tym również śmierci, spełniały funkcję dydaktyczną: miały bowiem uczyć człowieka prawidłowego funkcjonowania na ziemi, objaśniać mu poszczególne doświadczenia życiowe, odnalezienia się w chwili śmierci, a często zapewniać o kontynuacji żywota post mortem.

Mity, sprzeczne z rzeczywistością empiryczną, dowolnie ją przekształcały, a sam temat śmierci pojawiał się w nich niezwykle często. Ponadto mity doskonale tłumaczyły śmierć, ukazywały ją w innym, lepszym znaczeniu ${ }^{10}$.

Dwom poetkom - Bronisławie Ostrowskiej i Maryli Wolskiej, które rozpoczęły swoją drogę twórczą w okresie Młodej Polski, tematy związane z kruchością ludzkiej egzystencji, przemijaniem i wreszcie ze śmiercią były bliskie i często podejmowane $\mathrm{w}$ ich literackich tekstach.

Bronisława Ostrowska należała do drugiej generacji twórców młodopolskich. Biografia poetki nasycona jest faktami poświadczającymi jej artystyczną duszę. W ciągu

\footnotetext{
${ }^{9}$ Zob. P. Ariès, Pięć wariacji na cztery tematy, [w:] Antropologia śmierci. Myśl francuska, przekł. S. Cichowicz i J. M. Godzimirski, wstęp S. Cichowicz, Warszawa 1993, s. 284-300.

Ariès wyróżnił kolejno pięć obrazów śmierci: śmierć oswojoną, własną, śmierć przewlekłą i bliską, „twoją" śmierć oraz śmierć odwróconą. Poszczególne rodzaje śmierci uzależnione były od działania czterech parametrów: świadomości siebie, obrony społeczeństwa przed naturą, wiary w dalsze życie i wiary w istnienie zła.
}

Zob. tenże, Rozważania o historii śmierci, przekł. K. Marczewska, Warszawa 2007.

Zob. też tenże, Człowiek i śmierć, przekł. E. Bąkowska, Warszawa 2011.

${ }^{10}$ E. Cassirer, Funkcja mitu w życiu społecznym, przekł. H. Buczyńska, [w:] Filozofia i socjologia XX wieku, red. B. Baczko, t. 1, Warszawa 1965, s. 79. 
całego życia odbywała liczne podróże oraz nawiązywałą szerokie kontakty towarzyskie i zawierała artystyczne przyjaźnie, które następnie procentowały.

W 1905 roku Ostrowska opublikowała tom poezji zatytułowany Opale. Jej debiut poetycki zyskał pozytywne recenzje krytyków. Jak zaznaczyła Hanna Mortkowicz-Olczakowa:

Nazwa tomu „Opale” zdawała się błyszczeć w mroku tajemniczym światłem. Młode głosy drżały wzruszeniem. Melodyjny rytm załamywał się niepokojącą nutą ${ }^{11}$.

Wśród wierszy zgromadzonych $\mathrm{w}$ tym tomie wiele dotyczyło problematyki dekadenckiej, chociaż u Ostrowskiej miały one wymiar lirycznej tęsknoty za światem bez nędzy i marności ${ }^{12}$, i w których dominantę stanowiły doznania smutku i melancholii. W jej twórczości dostrzegano ślady stylistyki Juliusza Słowackiego.

Debiutancki tom artystki był poetyckim zapisem sztuki podmiotowej i liryki nastroju. Krytycy dostrzegli również zalety formy ${ }^{13}$, która cechowała się lekkością i swobodą, co nie zdradzało negatywnych trudów tworzenia:

[...] śpiewającym liściem jest dusza B. Ostrowskiej [...]. Pieśń przepaja ją na wskroś. Tworzenie u niej nie jest aktem woli, lecz po prostu nieprzepartym odruchem istoty, która stworzona została na to, aby śpiewać. Inna zaś rzecz, że te odruchy ujęte zostały w karby świadomej i umiejętnej zdolności artystycznej ${ }^{14}$.

Sama poetka, świadoma sztuki słowa, akcentowała ważność treści wewnętrznej, tego głębszego znaczenia, jakie niesie z sobą utwór literacki. W ostatniej rozmowie z Hanną Mortkowicz-Olczakową Ostrowska stwierdziła, iż:

${ }^{11}$ Cyt. za: H. Mortkowicz-Olczakowa, Wstep, [w:] B. Ostrowska, Wiersze wybrane, Warszawa 1955, s. 7.

${ }^{12}$ C. Jankowski zatytułował recenzję wierszy Ostrowskiej Poetka tęsknoty, „Kurier Warszawski” 1905, nr 170. Przy tej okazji określił, czym tęsknota w ujęciu Ostrowskiej jest: „tęsknota jest za czymś, co nie ma prawa nigdy się ziścić, tęsknota pełna rezygnacji i melancholii, motyw to przebijający się uparcie przez poezje Ostrowskiej raz po raz upostaciowiony. Uczucie tęsknoty było częstym motywem podejmowanym w jej twórczości lirycznej".

${ }^{13}$ Adolf Strzelecki na temat formy poetyckiej Bronisławy Ostrowskiej pisał: „Forma utworów jest zawsze bez zarzutu, wykwintna i skończona, wycyzelowana z niemałym kunsztem i wielką subtelnością”. Cyt. za: A. Wydrycka, „... Rytmów gatazeczki skrzydlate...”. W świecie poetyckim Bronistawy Ostrowskiej, Białystok 1998, s. 9.

Jednak w opiniach o drodze poetyckiej Ostrowskiej nie brakowało też słów krytycznych. Zarzucano poetce wtórność, która wynikała ze ścisłego związku jej poezji z epoką, w której żyła. Zarzut wtórności zastąpiono sformułowaniem „echowości”, które w zamyśle miało posiadać pozytywne konotacje. Poetka mogła odbijać tendencje epoki, co stanowiło wartość dodatnią. Mogło to być rozumiane jako wyraz emocjonalnego związku z czasami, w których przyszło jej tworzyć, a przez co jej teksty literackie zyskiwały rangę dokumentu z epoki. Por. A. Potocki, Polska literatura wspótczesna, t. 2, Warszawa 1912, s. 325.

${ }^{14}$ Cyt. za: A. Wydrycka, „... Rytmów gatazeczki skrzydlate...”. W świecie poetyckim Bronisławy Ostrowskiej, Białystok 1998, s. 10. Por. B. Olech, Harmonia, liryzm, trwoga: studia o twórczości Bronistawy Ostrowskiej, Białystok 2012. 
Barwa, smak, kultura słowa, melodia rytmu to nie dosyć. To jakby powierzchnia soczystego, puszystego owocu. Umiesz dobrze, czujnie wyrażać zmysłowe wrażenia i powierzchowne wzruszenia. To dużo, ale to nie wystarcza. Trzeba wiedzieć, co i po co się wyraża. Trzeba iść w głąb. Chodzi o treść wewnętrzną ${ }^{15}$.

Jak podkreśla Anna Wydrycka, Ostrowska nie należała do najbardziej reprezentatywnych poetek swojej epoki, jednak na ówczesnej mapie literackiej zajmowała miejsce ważne obok Antoniego Langego, Miriama i Kazimiery Zawistowskiej ${ }^{16}$.

W poezji młodopolskiej niezwykle ważne było bezpośrednie ukazywanie stanów emocjonalnych. Przeżycia i nastroje bliskie ekspresjonizmowi poetyckiemu stanowią fundamentalny wyróżnik strategii twórczej również Bronisławy Ostrowskiej. Obok nastrojów znużenia podmiotu lirycznego jej wierszy pojawiały się także opisy poetyckich wyobrażeń śmierci.

Interesującą formę młodopolskiej tanatologii przedstawiła Ostrowska w wierszu $Z$ tamtego brzegu należącym do cyklu Opale. Utwór ten stanowi liryczny przykład reinterpretacji znanego średniowiecznego motywu madame mors i zaadaptowania go do nowej XIX-wiecznej przestrzeni literackiej za pomocą zabiegu estetyzacji. Śmierć, w ujęciu poetki, pozbawiona jest elementów makabrycznych, które powodują strach i niepokój. Jej liryczny opis, wprost przeciwnie, wywołuje uczucia pozytywne i daje wyciszenie wewnętrzne.

Podmiot liryczny wiersza Ostrowskiej z niecierpliwością oczekuje nadejścia, zbliżającej się, pewnej tajemniczej kobiecej postaci. Analizując sytuację liryczną, możemy się domyślać, iż chodzi o Madame Mors, jednak w tekście nie ma bezpośredniego wskazania na Śmierć właśnie. Słowo to w wierszu nie występuje, lecz jest za pomocą szeregu obrazów znacząco zasugerowane:

Ja ciebie, cicha, widzę już

I pragnę cię ogromnie;

[...] Owiana kwieciem zwiędłych róż

Powoli spływasz do mnie.

( $Z$ tamtego brzegu, w. $1-4)^{17}$

Postać (kobieta), na którą czeka podmiot mówiący, pozbawiona jest oznak dramatyzmu skontaminowanego z elementami makabry. Epitety ją opisujące: „przepiękna”, „nieskończona”, „cicha”, „owiana kwieciem zwiędłych róż”, „spowita w obsłon białych śnieg”, „zadumana”, mająca „bladą twarz” wskazują na jej specyficzną „urodę”, nasuwają myśl o pewnej gwarancji wprowadzenia podmiotu w stan ukojenia, wyciszenia, wiecznego odpoczynku. Gradacja ta dokona się, gdyż obietnica przyjścia jest wiarygodna.

Również formy werbalne, które oznaczają podstawowe powinności śmierci, wskazują na łagodne, wręcz opiekuńcze, nigdy nie gwałtowne usposobienie tajemniczej

\footnotetext{
${ }^{15}$ Cyt. za: H. Mortkowicz-Olczakowa, dz. cyt., s. 5.

${ }^{16}$ A. Wydrycka, „...Rytmów gatąeczki skrzydlate...”, s. 11.

${ }^{17}$ Cyt. za: B. Ostrowska, Wiersze wybrane, Warszawa 1995, s. 19.
} 
Pani, które zasadniczo różni się od jej średniowiecznego wyobrażenia. Jednocześnie ukazują perspektywę dotarcia do bezpiecznej przystani:

Powoli spływasz do mnie

(Z tamtego brzegu, w. 5)

Wskazujesz tamten - cichy brzeg przejrzystą swoją dłonią

(Z tamtego brzegu, w. 9)

I zadumaną, bladą twarz otulasz w całun cichy

Za tobą płynie pieśni dźwięk

( $Z$ tamtego brzegu, w. 15-16)

Ostrowska wykorzystuje na potrzeby budowania świata poetyckiego motyw snu ${ }^{18}$. Śmierć w jej wierszu „owiana” jest „snem i wonią”. Zastosowana technika oniryczna stanowi próbę odrealnienia rzeczywistości poetyckiej i wprowadzenia podmiotu w krainę, w której prawa dyktuje sama śmierć. U Ostrowskiej jest ona stylizowana na Panią pochodzącą ze świata odległego, nierealnego, prosto „z tamtego brzegu”, jak ze snu.

Promesa rychłego spotkania ze śmiercią wywołuje w podmiocie ambiwalentne uczucia: z jednej strony pragnie on szybkiego znalezienia się na „tamtym [lepszym] brzegu”, $\mathrm{z}$ drugiej natomiast, ta nieuchronna wizja budzi w nim lęk. Wydaje się jednak, iż samo pragnienie jest wobec strachu dominujące, silniejsze. Słyszalny dźwięk pieśni, która rozlega się dookoła, otacza śmierć, wydaje się hipnotyzujący, przyciągający uwagę:

Za tobą płynie pieśni dźwięk

Rozwiany w wiatru tchnienie

Za tobą płynie pieśni dźwięk

A mnie ogarnia dziwny lęk,

Lęk wielki i pragnienie.

(Z tamtego brzegu, w. 16-20)

Podmiot liryczny w wierszu Ostrowskiej próbuje poznać tajemnicę śmierci, pragnie się w niej zanurzyć, a tym samym dotrzeć do istoty rewersu życia — pomimo, co należy podkreślić, odczuwanego strachu. Wydaje się, jakby podmiot chciał poddać się temu, co nieuniknione:

Ja ciebie, cicha widzieć chcę

Przepiękną, nieskończoną;

Ja ciebie jasno widzieć chcę -

Rozwiać całunów twoich mgłę

I paść na twoje łono.

(Z tamtego brzegu, w. 21-25)

\footnotetext{
${ }^{18} \mathrm{~W}$ mitologii greckiej personifikacją snu jest Hypnos, często przedstawiany jako śpiący młodzieniec. Był to bóg, który dotykając ludzi kwiatem maku, przynosił im sen i ukojenie. Hypnos to syn nocy, bliźni brat boga śmierci. Zob. J. Parandowski, Mitologia. Wierzenia i podania Greków i Rzymian, Londyn 1992, s. $156-157$.
} 
Na marginesie, porównywalny liryczny obraz zapadnięcia się w śmierć odnajdujemy w wierszu należącym do cyklu Rozmyślania II - Antoniego Langego: $O$ śmierci, gdy się $w$ tonie twym zanurzę... Przy tej okazji warto zaznaczyć, że zarówno Ostrowska, jak i Lange upatrywali w śmierci doskonalszą formę, dodajmy — nowego, życia. Poeta, pisząc „życie — śmierci doskonałośc” ${ }^{19}$, próbował zmienić negatywne i pełne trwogi nastawienie człowieka do niej.

Zabieg „oswajania” śmierci jest typowy dla młodopolskiej tanatologii, gdzie stworzenie upersonifikowanego wyobrażenia Madame Mors było odpowiedzią na strach wynikający z kruchości ludzkiego życia.

W wierszu Ostrowskiej następuje bardzo czytelne wskazanie na sens śmierci, która nie jest synonimem kresu, przeciwnie, jest zapowiedzią nowego, lepszego żywota. Śmierć w ujęciu poetki występuje w roli emisariuszki i przewodniczki zarazem, której zadaniem jest pomoc człowiekowi w płynnym i łagodnym przejściu „na tamten brzeg” — ku wieczności. Wyobrażenie śmierci w kreacji poetyckiej Bronisławy Ostrowskiej jest pełne dostojeństwa, ładu i harmonii. Jednak pojawia się też element niepokoju, poniekąd zrozumiały, gdyż podmiot oczekuje spotkania z czymś, czego dotąd nie doświadczył.

Liryczna wypowiedź Ostrowskiej mieści się w popularnym w końcu XIX wieku nurcie meditatio mortis. W jej wierszu człowiek zafascynowany jest śmiercią, jego myśli skoncentrowane są wokół niej. Wizerunek Madame Mors wykreowany przez poetkę skłania do bardziej odważnych rozmyślań o „tamtym brzegu”. Jest także dobrym wstępem do rozważań o życiu, okazją do podsumowań i ocen wydarzeń z lat minionych.

Ostrowska poszerza problematykę młodopolskiego portretu śmierci, przybliża jej spodziewany wygląd, rezygnując z naturalistycznego (i makabrycznego) opisu procesu rozkładu ciała i powstałego nieprzyjemnego efektu wizualno-wyobrażeniowego. Poetka skupia się także na dokładnym zarejestrowaniu nastrojów towarzyszących samemu podmiotowi, wyczekującemu śmierci.

Podobny wizerunek śmierci-ukoicielki kreśli Stanisław Korab-Brzozowski w wierszu $O$ przyjdź!, gdzie bezpośrednie wskazanie na śmierć następuje dopiero w ostatnim wersie wiersza, mimo iż w całej twórczości tego młodopolskiego artysty słowa pojawiają się z dużą frekwencją określenia wprost śmierć nazywające i ściśle z nią związane: groby, trumny i całuny. Zaniechanie w tym przypadku nazwania w pierwszej kolejności adresatki wiersza oraz odpowiedni dobór słownictwa ją określającego spowodowały, że śmierć odebrana została jako pełna uroku i powabu, subtelna kobieta ${ }^{20}$ :

O przyjdź jesienią

Wdziej szatę lekką, białą, zwiewną,

Pajęczą:

[...] I dłonie

Swe przejrzyste, miękkie woniejące

\footnotetext{
${ }^{19}$ Cyt. za: A. Lange, Rozmyślania XX, [w:] tenże, Rozmyślania i inne wiersze, Warszawa 1979, s. 78.

${ }^{20}$ Wyobrażenie śmierci jako delikatnej kobiety przypomina typ kobiet wywodzących się rodem z utworów Juliusza Słowackiego. Zob. A. Lubaszewska, dz. cyt., s. 52.
} 
$\mathrm{Na}$ cierpiące

Połóż mi skronie -

O Śmierci!

(O przyjdż!, w. 1-3, 17-21) $)^{21}$

Zbieżny w obu wierszach (Ostrowskiej i Korab-Brzozowskiego) jest także sposób operowania barwami, głównie bielą 22 oraz zmysłem powonienia.

Bronisława Ostrowska, prowadząc liryczne rozważania o śmierci, ukazuje ją również jako służebnicę:

Dobra, służebna Śmierć

(wiedz, że nie forma to pusta

Twarz w światło i czarna chusta!)

Przed czem, o przed czem ci drżeć?

I oczy ujrzały moje

Gwiezdnych gościńców spokoje

Ku nim, tęsknoto, leć!

(Dobra, stużebna śmierć, w. 1-7 $)^{23}$

W tej następnej odsłonie śmierci została uwypuklona przez poetkę jej funkcja wyższej użyteczności względem każdego człowieka. Otóż śmierć to pośredniczka między dwoma światami - doczesnym, chwilowym i tym drugim, do którego prowadzi całe życie, i za którym podświadomie się tęskni. Docelowy zaświat jawi się w wierszu Ostrowskiej jako kraina, w której panuje wszechobecny spokój. Pozytywne oblicze i rola, jaką ma do spełnienia Pani Śmierć, zupełnie wykluczają możliwość odczuwania strachu ze strony podmiotu mówiącego. Jej jedynym atrybutem, który może wzbudzać respekt, jest „czarna chusta”, jednak moc negatywnego oddziaływania śmierci, pośrednio przez kolor nakrycia głowy, zostaje zniwelowana poprzez ustawienie twarzy samej śmierci w kierunku światła, które może wskazywać na obecność dobra, czyli Stwórcy.

Łagodne mówienie o śmierci Bronisława Ostrowska osiaga także za pomocą symboliki kwiatów ${ }^{24}$. Taka liryczna sytuacja następuje w wierszu Po kwiatach, należącym do cyklu Opale:

${ }^{21}$ Cyt. za: S. Korab-Brzozowski, Poezje zebrane, Kraków 1978, s. 23.

${ }^{22}$ Ostrowska buduje swoje poetyckie pejzaże za pomocą jasnych barw: przede wszystkim żółtej/złotej, błękitnej i białej. Biel w tradycji symbolicznej to barwa światła będącego zaprzeczeniem ciemności, jest symbolem początku, ale i końca. Oznacza także żałobę.

O symbolice bieli pisała M. Rzepińska, Historia koloru w dziejach malarstwa europejskiego, Warszawa 1989 , t. 1 , s. 125 i nast.

O symbolice innych kolorów zob. też: R. Gross, Dlaczego czerwień jest barwą mitości, przekł. A. Porębska, Warszawa 1990.

${ }^{23}$ Cyt. za: B. Ostrowska, Pierścién życia: Tartak stoneczny, t. 4, oprac. L. Piwiński, Warszawa 1932, s. 81.

${ }^{24}$ Liryka młodopolska chętnie posługiwała się roślinną symboliką. Ostrowska wzbogaca florystykę młodopolską głównie o rośliny swojskie, które wraz z odpowiednio dobranymi środkami stylistycznymi tworzą niezwykły obraz świata natury, tak ważny dla poetki. Na temat symboliki poszczególnych kwiatów pisał Ireneusz Sikora. Zob. I. Sikora, Symbolika kwiatów w poezji Młodej Polski, Szczecin 1987; ten- 
A kwiaty zbladłe i smętne ogromnie

Kładą się łanem pod chłodną jej nogą,

Pokotem kładą się, drżąc nieprzytomnie,

I główek podnieść od ziemi nie mogą

I tak po kwiatach śmierć zbliża się do mnie...

(Po kwiatach, w. 1-5) $)^{25}$

Przy tej okazji warto zaznaczyć, że młodopolska literatura chętnie sięgała po obrazy i figury ze świata fauny i flory. Źródła tego zabiegu należy upatrywać w upodobaniu modernistów do języka symbolicznego, który pozwalał na łatwiejsze wyrażenie treści trudnych ${ }^{26}$. Dużą rolę w występowaniu motywów florystycznych odegrała tzw. „mowa kwiatów", co wiązało się z ogromną popularnością tekstów opartych na symbolicznej interpretacji roślin.

Natomiast Maryla Wolska ${ }^{27}$ — ważna osobowość lwowskiego środowiska artystycznego Młodej Polski — od urodzenia miała niezwykłe szczęście do otaczania się ludźmi uzdolnionymi artystycznie. Już we wczesnym dzieciństwie nauczyła się rozpoznawać dzieła malarskie najwybitniejszych mistrzów pędzla. Sama także zaczęła przejawiać zdolności plastyczne ${ }^{28}$. Środowisko twórcze, w którym dorastała, wywarło wpływ na całe jej późniejsze życie. Równolegle obok talentu malarskiego zaczęły rodzić się umiejętności literackie ${ }^{29}$. Jednym z pierwszych napisanych utworów była powieść (ilustrowana rysunkami Maryli) - Nasze chtopcy. Pisała również wiersze: Pożegnanie Marii Konopnickiej i Juliuszowi Stowackiemu ${ }^{30}$. Przez badaczy i krytyków nazywana była, podobnie jak Ostrowska, poetką tęsknoty, pragnień i żalu nad przemijaniem czasu. Jej wiersze są nacechowane oczekiwaniem i niecierpliwością. Poetka daje pierwszeństwo rezygnacji, refleksyjnemu rozrachunkowi z życiem, a przede wszystkim doświadczeniu śmierci.

Motyw ten w jej lirycznych tekstach ulegał modyfikacjom. Warto zaznaczyć, iż pod koniec życia poetki stał się dominujący w jej twórczości, czego artystycznym wyrazem jest zbiór wierszy zatytułowany Dzbanek malin (1929). Ten ostatni opublikowany to-

że, Mtodopolska florystyka poetycka, Wałbrzych 2007; tenże, Przyroda i wyobraźnia. O symbolice roślinnej w poezji Mtodej Polski, Wrocław 1992.

${ }^{25}$ Cyt. za: B. Ostrowska, Poezje, Warszawa 1932, s. 123.

${ }^{26} \mathrm{Na}$ temat wykorzystywania symboli w poezji Młodej Polski pisała M. Podraza-Kwiatkowska. Zob jej pracę Symbolizm i symbolika w poezji Mtodej Polski, Kraków 1994.

${ }^{27}$ Rodzicami Maryli z Młodnickich Wolskiej była Wanda z domu Monné (1850-1923) - uzdolniona muzycznie, autorka wielu książek dla dzieci i przekładów. Napisała nowele: Kartka życia, Na progu stawy, W pótcieniach pracowni - publikowane w czasopismach. Tłumaczyła także z Hansa Christiana Andersena i Aleksandra Dumasa.

Zanim Wanda wyszła za malarza Karola Młodnickiego, była narzeczoną Artura Grottgera.

${ }^{28}$ K. Zabawa, Wstęp, [w:] M. Wolska, Poezje wybrane, wstęp, wybór i oprac. K. Zabawa, Kraków 2002, s. 6.

${ }^{29}$ Wśród opinii na temat kunsztu poetyckiego Wolskiej pojawiały się także te negatywne. Zarzucano poetce brak inwencji twórczej, jej dorobek określano jako epigoński. Z podobnymi głosami krytyki spotkała się, o czym wspomniałam wcześniej, twórczość Bronisławy Ostrowskiej. I to nie jedyny „wspólny mianownik" uprawianej przez nie sztuki słowa: obie były poetkami raczej zapomnianymi i niedocenianymi.

${ }^{30} \mathrm{~K}$. Zabawa, dz. cyt., s. 16. 
mik wierszy Wolskiej, podobnie jak debiutancki tom Bronisławy Ostrowskiej, zyskał pozytywne recenzje. Krytycy podkreślali świadomą postawę poetki przejawiającą się odpowiednim doborem wierszy budujących zbiór. Akcentowali również wyjątkowy, dojrzały nastrój liryczny wszystkich tekstów. Wewnętrzny przekaz jej wierszy jest charakterystyczny dla ostatniego etapu twórczości. Tchnie on wyciszeniem, spokojem wynikającym z mądrości przeżytych lat i zdobytych doświadczeń31.

Temat śmierci w tym zbiorze został połączony z motywem stałego odradzania się przyrody. Wolska w swoich wierszach traktujących o śmierci prezentowała postawę pogodzenia się $^{32} \mathrm{z}$ nieuchronnością zakończenia ludzkiego żywota. Poetka doskonale zdawała sobie sprawę z tego, że kiedyś przyjdzie jej pożegnać się ze światem doczesnym. Pisała:

Im straszniejsza, nikczemniejsza rzeczywistość, tym niżej kłaniam się w podzięce szczęśliwemu, bogatemu, pięknemu życiu, jakie mi Bóg przeżyć pozwolił, tym wdzięczniej błogosławię pamięć Ich wszystkich, którzy je tak szczęśliwym, bogatym, pięknym uczynili!

Niechże mi oni jeszcze i śmierć nie za późną, miłosierną uproszą! Amen ${ }^{33}$.

Wydaje się, że w rozumieniu Wolskiej świadomość nieuchronności śmierci nadaje sens dotychczasowemu życiu, ta świadomość wzbogaca je o ważne refleksje. Stanowi asumpt do odbycia mentalnej wędrówki w głąb siebie celem dokonania podsumowań, oceny minionego etapu, często być może subiektywnej i rozliczeń z samym sobą i z otoczeniem. Zbliżająca się perspektywa odejścia porządkuje życie w taki sposób, że jawi się ono bardziej przejrzyście, a postawa człowieka wobec niego staje się bardziej przytomna.

Doświadczenie śmierci w ujęciu poetki jest równoznaczne z odpoczynkiem. Stanowi również ostateczne zakończenie wszelkich doczesnych cierpień oraz przynosi rozwiązania męczących problemów codzienności. W takiej sytuacji śmierć, zdaniem Maryli Wolskiej, wydaje się wręcz upragniona, gdyż stanowi ucieczkę od trosk i rozczarowań ziemskiego życia:

Przyjdzie czas, gdy mi wszystkie radości i smutki

Jedno będą. Wydzwoni życie i tak stanę

Jako zegar... W zimowy może dzień przykrótki

Kurantowa melodia nagle się w urwane,

Sypkie nutki rozpryśnie i tak, gdzie los zdarzy,

Wstrzyma cichą wskazówkę na zegara twarzy...

[...] O, gdyby móc uprosić o powrót dla ducha

[...] I tak paść na pobrzeżne błonie tamtej strony...

(Przyjdzie czas, w. 1-6, 9, 11) 34 $^{34}$

\footnotetext{
${ }^{31}$ S. Sierotwiński, Maryla Wolska. Środowisko, życie, twórczość, Wrocław 1963, s. 17.

${ }^{32}$ Receptą na zmienność i przemijalność życia jest stoicki pogląd filozoficzny mówiący o tym, by w każdym położeniu oczekiwać śmierci z otuchą i spokojem, żyć w przeświadczeniu, że to nic innego, jak rozkład pierwiastków, z których składa się każde stworzenie. Śmierć jest więc zgodna z prawami natury, zupełnie niezależna od człowieka. Zob. J. Legowicz, Filozofia starożytna Grecji i Rzymu, Warszawa 1970, s. 305.

${ }^{33}$ Cyt. za: M. Wolska, Quodlibet, [w:] M. Wolska, B. Obertyńska, Wspomnienia, Warszawa 1974, s. 215.

${ }^{34}$ Cyt. za: M. Wolska, Poezje wybrane, s. 460.
} 
Z rozważań o śmierci, która jest jedynie kolejnym ogniwem życia, tchnie spokój i pewność przyszłości. Taka śmierć wycisza, daje ukojenie. Takiego właśnie zakończenia życia pragnie podmiot mówiący jej wierszy. Można zaryzykować stwierdzenie, iż śmierć jest wręcz marzeniem podmiotu lirycznego, którego ziszczenia niecierpliwie oczekuje:

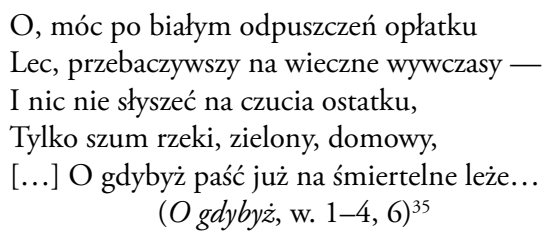

Podobnie jak liryczny bohater wierszy Bronisławy Ostrowskiej i Antoniego Langego, podmiot wiersza Maryli Wolskiej również pragnie zanurzenia w śmierci. Gest taki przywodzi na myśl potrzebę doznania poczucia bezpieczeństwa i zasygnalizowanie chęci odpoczynku.

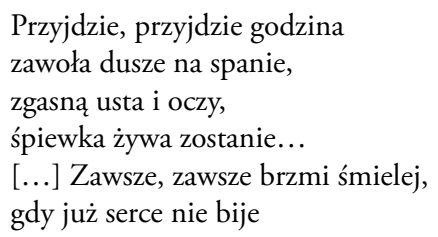

Poetka, pisząc „przyjdzie, przyjdzie godzina...”, wyrażała świadomość nieuchronnego i zarazem uniwersalnego, a przez to „oswojonego” charakteru śmierci. Postawa ukryta w lirycznych tekstach Maryli Wolskiej polegająca na antycypowaniu tego doświadczenia jest jedną z metod przezwyciężenia lęku przed nią. Analizując wiersze poetki, czasem odnosi się wrażenie, jakby przez większą część lat poetka wypatrywała końca swojego życia.

Warto zaznaczyć, że mimo iż sporo miejsca w swoim dorobku poetyckim poświęca temu tematowi, śmierć nazwana wprost występuje niezwykle rzadko. Najczęściej ukryta jest pod symbolami i omówieniami. W rozpoznawaniu motywu śmierci w lirycznych tekstach poetki pomaga leksyka związana z określeniami czasu (zegar), symbolami akwatycznymi (woda), kierunkiem (tamta strona, tamten brzeg). Podobnie jest zresztą u Bronisławy Ostrowskiej.

Śmierć w poetyckiej refleksji u prezentowanych młodopolskich twórców, głównie dwóch poetek - Bronisławy Ostrowskiej i Maryli Wolskiej została „oswojona”, a jej doznanie - ukojone, dzięki zastosowaniu zabiegu estetyzacji. W literaturze i sztuce

\footnotetext{
${ }^{35}$ Cyt. za: tamże, s. 459.

${ }^{36}$ Cyt. za: tamże, s. 457.
} 
Młodej Polski estetyzowano śmierć, co wiązało się z postrzeganiem tego doświadczenia jako przejścia w inny, pozytywnie wartościowany wymiar, rodzaj łagodnego snu — jednak bez narzucania odbiorcy widoku ciała ulegającego rozkładowi. Śmierć człowieka wiązano tym samym z wyswobodzeniem go z materialnego, cielesnego więzienia, które krępowało wolną duszę. Skoro ciało było przynależne materii, czyli temu, co złe, to śmierć była zatem wyzwalającą ucieczką, wręcz nagrodą dla zmęczonego życiem człowieka.

Motyw śmierci przebiega przez znaczącą część twórczości obu poetek. Biorąc pod uwagę fakt, iż śmierć jest jedynym pewnym zdarzeniem na drodze każdego człowieka, i że opuszczenia świata doczesnego nie da się uniknąć, Bronisława Ostrowska i Maryla Wolska nakreśliły pozytywny i kojący projekt (poprzez symbolikę kwiatów i kolorów, metaforykę akwatyczną, łagodny w wydźwięku dobór środków stylistycznych, głównie epitetów przy opisywaniu śmierci), przygotowania się na nieznane dotąd doświadczenie przejścia w krainę zaświatów.

W ich ujęciu śmierć nie jest przeżyciem przesiąkniętym na wskroś grozą. Spotkanie z Madame Mors może być długo wyczekiwanym i upragnionym momentem na drodze człowieka do wieczności. Jest również okazją do przyjęcia krytycznej postawy wobec życia, które kiedyśs się skończy.

Ponadto młodopolskie wyobrażenie śmierci-piastunki stanowiło odpowiedź na dekadenckie znużenie światem i obawy związane ze spodziewanym kresem żywota.

Aldona Jankowska

\author{
The Death-Nanny Give Relief \\ About Images of Death in Literary period Young Poland \\ in the Selected Poems of Bronisława Ostrowska and Maryla Wolska
}

\title{
Summary
}

My concept of the article was to present the death in literary period Young Poland. The article basis of selected poems of Bronisława Ostrowska and Maryla Wolska.

The death and love were in Young Poland movement main literary subjects. In literary period Young Poland differently a death was understood — as the beautiful, gentle women —Madame Mors — the reverse of Danse macabre. The death-nanny give relief and calm.

This motive and kind of the death was very popular in Young Poland literary period. 